\title{
Theatrical Dialogue in Teaching the Classics
}

\section{Forthcoming May 2017, Journal of Classical Sociology 17(4)}

Isabelle Darmon

University of Edinburgh, UK

Carlos Frade

University of Salford (Manchester), UK

\begin{abstract}
This article addresses some fundamental affinities between theatre and teaching and is based on emerging work in a long-term experiment which we began in the conference 'Weber/Simmel Antagonisms: Staged Dialogues', held at the University of Edinburgh on December 2015. Aimed at exploring the possibilities of the theatrical and dialogical forms for teaching the classics of social and cultural theory, it is a risky experiment whose initial results are presented in this special issue. In order to introduce the dialogues and situate them in the context of the broader project, the article does three things: first, it expounds the process of subjectivation at work in both theatre and teaching and explores some of the modalities of the subjective shift sought for in spectators and students. Second, it explains the specificity of this experiment by contrasting it with other uses of theatrical dialogue in teaching. Finally, before briefly introducing each of the dialogues, the article clarifies the fundamental difference between the dialogical form and debate, as radically separating them is at the heart of any experiment in subjectivation, away from the stirring of opinions.
\end{abstract}

\section{Keywords}

Badiou, dialogical form, social science teaching, subjectivation, subjective process

To put Weber and Simmel in theatrical form, no matter how modestly, and to do it with an educational aim in mind may be considered an innocuous academic game, or perhaps a dubious endeavour, detrimental to both theatre, even if Weber's and Simmel's antagonistic positions are a subject matter amenable in principle to theatre, and education, the proven productive value of comparisons and contrasts notwithstanding. And yet, it is precisely such a risky and long-term experiment that we began in the conference 'Weber/Simmel Antagonisms: Staged Dialogues', held at the University of Edinburgh on December 2015. This is only a first step, it must be emphasized, and it is a selection of the dialogues read-staged at the conference that is presented in this special issue. 


\section{Theatre, teaching and subjectivation}

The Edinburgh conference is in continuity with a seminar series on Weber's thought we have been conducting in the last years. Entitled 'Thinking the Present with Max Weber', the series is an attempt to bring Weber's thought to bear on our present, an ambitious aim which requires to go beyond mere scholarly interests and the petrified and petrifying canon they tend to promote (Darmon and Frade, 2013). But the staged dialogues conference was meant to take a step further in that direction and eventually break with the canonical image of Weber as founding father, 'domestic idol' (Hennis, 2000: 4) and any other made-to-measure homely figure of authority or heroism, as an impediment to grasp thought and, if there is thought, to make its power manifest today, e.g. in the classroom. The usual problem with scholarship is that, in researching and presenting a thinker's work, it tends to develop an impulse to fix that thinker's thought and thereby tacitly or explicitly neglect the living character of thought, that is, ultimately its independence from the historical and social conditions in which it was born and therefore its universality. Indeed the task of subjecting Weber's or Simmel's thought to the test of a confrontation with times and conditions other than those from which it sprang, a task essential to grasp that thought and appraise its real power, is different from scholarship, even if its successful accomplishment will necessarily draw on existing scholarship. But scholarship becomes scholasticism as soon as it behaves like the jealous custodian of a canon which leads it to dismiss any non-canonical use of thought, regardless of how fecund it may be.

What brought us to the idea of calling upon Georg Simmel and staging Weber/Simmel antagonisms in the form of imagined dialogues was precisely our desire to subtract Simmel and even more so Weber from the established canons that a very prolific scholarship has erected for nearly one century now, as well as to explore new possibilities for teaching the classics. This attempt to defamiliarize Weber and Simmel and break with the inertia of the already traversed paths does not imply any lack of rigour or seriousness, let alone a betrayal of these two thinkers - indeed we would hope that it testifies to an attempt towards a more real fidelity, a fidelity to their thought as a living force. In what concerns teaching, the idea is precisely to show the productive character of Weber's and Simmel's thought in the classroom and beyond. What truly matters in carrying out this task is the transmission of something other than knowledge, something which will enable students to use their capacity for thought and thereby abide by the order of thinking, and it is at this very point that the experiment involved in the imagined dialogues may play a role.

Of course, awakening students to the power of thought, in this case to that of the 'classics', will take more than writing and performing lively dialogues! Not only scholasticism, but the very conditions of the University, and more generally of education, weigh heavily on the students' desire 
- or lack of it. What forms must one give to educational transmission, when anything to do with education in any real or at least reasonable sense of the word is bound to take place in the midst of the current destruction of education? Unfortunately 'destruction' is exactly the right word; it is a relentless process that today takes place on an everyday basis and at all levels: endless government policies, the so-called 'teaching' 'excellence' framework in the UK being the latest and perhaps most lethal one, a managerial class which build their careers by devastating universities, and our continued submission as academics. In this context, the one thing needful, almost desperately so, in terms of teaching lies in creating an educational, i.e. teaching and learning and vice versa, situation such that a subjective shift may happen, that is, a situation which, by interrupting the dominant opinions and switching off the subjective dispositions that ever more students bring to the classroom (although considerably less than one would expect taking into account the extremely harsh lives students lead today, their subjection to the yoke of debt and the poisonous ideology which goes with it, to name only the most evidently unbearable injustices), makes it possible that thinking may start to take place. Today this is an absolute pre-condition of what, in Science as a Vocation and Profession, Weber deemed 'the most difficult pedagogic task of all', namely, 'the presentation of scientific problems in such a way that an untrained but receptive mind can understand them and - crucially - go on to think about them independently' (Weber, 2008: 30). Indeed unless the triumphant contemporary injunction 'do not think, adapt' is defied and defeated, no successful accomplishment of such pedagogic task will ever take place. For today more and more students come to the university, not as the 'untrained and receptive mind(s)' Weber thinks of, but already indoctrinated and infantilized as clients and seekers of enjoyment, a process the university itself takes care to intensify as soon as students arrive, so that arousing their minds' receptivity is the pre-condition of any education worthy of the name. But, in the current situation, this has become an even more difficult task than the one Weber refers to.

And yet, teaching has never been an easy task at all. As an art and not only a craft, one certainly aided by a variety of techniques and procedures, but impossible to reduce to the latter, teaching is exposed, as teachers know too well, to the 'trial of chance' (Badiou, 2005: 74). Here lies a fundamental link with the theatre: in the fact that every performance, and a lecture is also a performance, is rather singular, a distinct occurrence. Its success is fundamentally determined by the subjective participation of the students, a form of participation which needs not resort to moving students from their seats and having them engaged in classroom activities, all the more so when the latter are such that, as is the case today with voting and other formally participatory classroom tasks which simply reproduce the dispositions and habits promoted by the new media and the dominant discourses, they may actually maintain students in conformist passivity, however frenetic their activity may be. Indeed the subjective transformation sought for - a transformation essentially 
concerned with arousing the students' receptivity, awakening their desire or, as Weber would say, their 'daemon', and getting them to abide by the constraint of consistency and more generally by the discipline of thought - can perfectly take place even if the students are quiet and immobile in their seats. As can be seen, there is a deep affinity between the theatrical situation and Weberian social science teaching - an affinity not so much to do with performance as with a process of subjectivation at work.

True theatre or 'Theatre' according to Alain Badiou, 'should make it known to you', the readerlistener, above all the students but in truth any one, including academics (after all, are not academics also students?), 'that you will not be able innocently to remain in your place' (Badiou, 2013: $§$ XXIV, original emphasis). Being summoned to choose and take a stance is a real effect, and a Weberian motif par excellence, for even if one lazily decides to remain in the place one already is, or - which in practice amounts to the same - to evade 'the plain intellectual duty of integrity that occurs when one does not have the courage to be clear about one's own ultimate standpoint', yet nothing is likely to be the same, as one will not be able to resort, in all innocence and with good conscience, to the usual 'feeble relativization' (Weber, 2008: 52) to justify one's conduct of adaptation and submission to the world as the world is. In such conception, theatre encourages a shift from a life that, as Weber argues in the essay on value-freedom in what is perhaps the most Platonic moment of all his work, simply 'slip(s) by', to a 'consciously conducted' and thus at least in part inwardly determined life (Weber, 2012: 315, translation modified).

\section{Theatrical dialogue and the teaching of social theory - a short and selective review}

It is the subjective process cutting across Theatre and Weberian social science teaching that we find important to investigate and explore further. The conference on imagined dialogues is, as said, a very preliminary step in such a project. Nevertheless, setting ourselves such a horizon, however farfetched, does distinguish the spirit of this exercise from that of other initiatives.

Theatre has for example often been used in a supplementary or remedial function in social sciences teaching, where it has been mobilised as a vehicle, alongside other arts, for reengaging disaffected students (for accounts of such efforts, see the journal Teaching Sociology).

Closer to our experiment is Bruno Karsenti's and Bruno Latour's use of theatrical dialogue for the exposition and clarification of key intellectual antagonisms, the most famous example being the reconstruction of the Tarde/Durkheim debate which took place in 1903 at the École des hautes études sociales (Vargas et al., 2008). This was one of numerous initiatives impulsed in recent years by or with Bruno Latour, whose longstanding interest in bringing 'science', theatre (and art) and politics together has taken multiple forms, well worth addressing here with a view to clarify our 
own endeavour further. As far as the Tarde Durkheim dialogue is concerned, first, the enduring and structuring character for social science of the difference between the two thinkers was not manifested so much in the dialogue itself, which was strictly arranged on the basis of the scrupulous collection of quotes from the work of both authors, as in the very staging of this dialogue today by two eminent French figures of social theory whose work connects with the sociologist they each acted as (Karsenti as Durkheim, Latour as Tarde). The debate thus contributed to the endeavour to retrieve Tarde for contemporary social theory, and implicitly pointed viewers and readers to the work of Latour and Karsenti for an understanding of what the Tarde/Durkheim antagonism might mean today.

Latour's mobilization of dialogue has taken other forms such as a dialogue between teacher and student, in the manner of, such was the claim, 'a (somewhat) Socratic dialogue' (Latour, 2004), and that of conversations between friends engaged in intellectual controversies, in a manner somewhat reminiscent of the philosophical dialogues of the Enlightenment, one of whose summits was abbe Galiani's Dialogues sur le commerce des bleds (Dialogues on the commerce in wheat), an absolutely exceptional work whose lightness and wit reportedly led Voltaire to praise it as a cross between Plato and Molière. In the same way as eighteenth century philosophical dialogues tuned in with salon conversations between educated people, the dialogue staged by Latour (2009) between two PhD students on 'two systems of sociology' at the same time as on gender will have brought a smile of recognition on the faces of French academics and students. Dialogue here has purposes of (witty) clarification for the not-yet or would-be inner circle.

Finally it is worth mentioning Latour's more recent and more direct engagement with theatre, through a project in collaboration with the Théâtre des Amandiers and 200 students aimed at staging imaginary but 'realistic' COP 21 negotiations ahead of the event (UN conference on climate change, 2015, Paris). As announced in the event leaflet:

'Truly a rehearsal for the negotiations at the international climate summit, this simulation, which will mobilise the means of social sciences, theatre, cinema and the arts, will transform the theatre into a place of experimentation and inventiveness, and gather artists, researchers and students so that they may imagine and experiment other modes of representation of the climate negotiations' (Nanterre-Amandiers and Sciences Po, 2015).

This theatrical form is very different from the one we have outlined in the above pages. In line with the masters programme SPEAP (Programme of Experimentation in Political Arts) at Sciences Po, of which Latour is founding director, theatre here is called upon to fulfil a function of capacitation and training focused on fostering a heightened sensibility and enabling new forms of representation 
of major political problems, above all climate change and the ecological crisis. Two crucial presuppositions underlie this form of theatre: first, it is built upon what we would call a stakeholders approach, of course involving the equal participation of non-human actants and human-made instruments to communicate with them, as befits Actor Network Theory. Theatre is meant to capacitate those stake-holders to take into account their different opinions and negotiate in a sensible manner their different interests, always within the existing situation, taken as a given. Second, it presupposes a consensual audience, a figure rather questionable as, if not indeed contrary to, a theatrical public - an audience certainly holding different opinions and sensibilities, but unanimous in their desire for the success of the negotiations on climate change. As the audience shares this imaginary subjectivity, nothing can really happen in this theatre other than the successful deployment of a project defined in advance.

These presuppositions together with the overall model they sustain seem to be taken to the 'Gaïa Global Circus' (GGC, see Latour, undated A and B), a full-fledged theatrical project which, in a way somewhat reminiscent of the aforementioned eighteenth century dialogues, performs science and politics in a theatrical fashion, combining tragic, comic, mythical and ritualistic elements. We cannot dwell here on the complexity of the GGC project; however, given its fundamental educational implications, we would like to summarize what we see as its major traits. GGC mobilizes theatre to throw on a multiform stage which is 'an actor in its own right', 'the cacophony of human positions on ecology' (Ghosn and Jazairy, 2016) and thereby explore the accompanying disputes, dramas and 'range of passions' (Latour, undated B) it triggers and sustains, all done with a view to widening human beings' sensitive, perceptive, representational and emotional repertoire for relating to 'Gaïa', a multifaceted character in the play made up of religious, millenarian and moral references which undergoes painful and destructive metamorphoses. It would thus seem that it is thanks to the fantasy of a moral Gaïa, a suffering and ultimately benign Gaïa, which underlies the GGC project that a reconciled humanity may come to their senses. Theatre here leaves behind its tortuous relations with the state and enters into a kind of symbiosis with it; only now the state is a World State, or the spectre thereof, and theatre stands for the end of political divisions and the beginning of an altogether different, post-human History.

\section{The dialogical form and its possibilities}

Consistently with the framework presented in section I, we looked to dialogue for its possibilities for subjectivation processes. Naturally the idea of 'dialogue' immediately suggests Plato's astonishing invention, and although it would be preposterous to conceive of our experiment as an attempt to write and stage Platonic dialogues, or variations thereof, there can be no denying that 
this dramatized philosophical form was a major and unavoidable source of inspiration for our broader project. For the dialogue as a form of investigation involves simultaneously and inseparably an inner and an outer quest whose importance is such that if the ego or self remains the same after the dialogue, then one can say that the dialogue has not happened. In other words: no true dialogue can take place which does not lead to a general modification of the thinking subjectivity (Badiou and Kakogianni, 2015: 60-61). The crucial opposition here is that between dialogue and debate, as the former seeks to interrupt the rule of opinion promoted by the latter and thus each and every feature characterizing the debate: its foundation, the supposed equality of opinions; its unfolding, the anodyne or hysterical confrontation of opinions; and its result, that is, the impossibility of reaching a rational conclusion and therefore the need to resort to external means, e.g. counting of favourable and contrary views. Indeed dialoguing is to interrupt other discourses, not only the discourse of opinion but also those of expertise, success and enjoyment, in order to test them out while testing oneself out, all done with a view to distance and ultimately liberate oneself and others from such discourses - discourses into which, given their power of attraction and the pressure to obey them, one can always relapse (Dixsaut, 2016: 43).

Imagined dialogues thus appeared to us as a very apt theatrical form to begin the experiment whose main orientating lines have just been outlined. The fact that the dialogues stage Weber's and Simmel's antagonistic positions at different levels, including in terms of their radically different characters, seems equally very fitting both theatrically and from a teaching standpoint. It is also important to emphasize that the dialogues are meant to be imagined but real in the sense of not merely historically believable or plausible but compelling in thought, persuasive in inviting the reader-listener to draw and unfold its implications in the present, and not recoiling from exposing the gaps and 'unthoughts' in Weber's and Simmel's fundamental positions.

The dialogues we present in this special issue are the result of an initial stage in a broader project, as we have emphasized, to explore the possibilities of the theatrical and dialogical forms to teach the classics. As to the extent to which they make a significant contribution to this initial stage in a much broader experiment, it is up the JCS reader to judge. To confer to such dialogues a dynamics and power of conviction emulating that of theatre takes inventiveness and ability, and probably more than that. Aware of our inevitable weaknesses in this respect, and yet determined to take the risk, we built an iterative process whereby, as authors, we exposed ourselves to some challenging tests: writing dialogues, and not just journal articles, and reading-performing them at the conference, in front of a (mainly academic) audience; secondly, once the dialogues had been finalised or rewritten after the conference, the test of reviews not only by Weber and Simmel scholars and experts in cultural sociology, but also coined by people from the theatre or involved in 
theatre studies. Reviewers took their role extremely seriously and generously offered much advice for turning what had often started as academic papers interspersed with dialogical punctuation into livelier exchanges between more distinct and marked characters, and with rhythm and some lightness to them. This was an unusual and sometimes difficult process, but all authors were determined to respond to the challenge, which, in some cases, implied yet another significant iteration in the writing of the dialogues. The pain may have been soothed by the praise received from the social science scholars, who seemed to have thoroughly enjoyed themselves in reviewing these pieces and found them not only stimulating and rigorous, but also refreshing and lively enough to their taste. The review process thus made manifest a broader gap than expected between social science scholars and people related to the theatre.

As befits the experimental nature of the project, the set of dialogues presented here are rather different not just in the topics they address but in the use of theatrical resources they make. However all seek to bring a sense of realness of the dialogue and of the presence of the two thinkers and their engagement with each other, as indeed is required for any theatrical performance to have any effect. But this is not necessarily achieved through the literal use of quotes or the biographical exactitude of situations. Quite the reverse: realness on stage is not likely to come from verisimilitude. The dialogues presented in this special issue looked for other keys to realness. Some looked for a degree of plausibility of situations, but a plausibility with which to play, so as to heighten the sense of distance and artificiality, and perhaps in this way convey something of the elaborate intellectual constructions being erected between our two thinkers, indeed perhaps even a sense of play between two men busy with theoretical wrestling and joint enquiry. Thus both Parker and Stanworth's and Haerpfer and Kaden's dialogues (respectively on the picture frame and on norms, rules and laws) create an imaginary encounter, yet also take great care in laying out the details of the two men's lives at those times, conveying a certain plausibility to these situations. This playful setting of the scene is consistent with the tone adopted in the dialogues, one in which the two men are seen jointly exploring areas of joint interest, helping each other out in their constructions, and developing thoughts which we now know came to fruition in later works... or not (as audience, we are thus almost persuaded that Weber's idea for the basic sociological concepts had been formed in his discussion of Stammler with Simmel! But Simmel's encouragement to his friend to develop his own theory of the frame inspired by his enquiry on rationalisation did not prosper, as far as the authors, and ourselves, know - whereas Simmel's own explanation, to Weber, of his analysis of light will find its place in his future book on Rembrandt). Fitzi and Mele's dialogue, set at a time of great uncertainty for Simmel, who was waiting to hear about a possible position at the University of Heidelberg, takes a less playful, more strained, look at Weber's and Simmel's exchange on a topic close to Simmel's concerns, on work and character, or 
personality. However, here too, the dialogue reveals surprising resonances between Simmel's theory of laziness and Weber's analysis of asceticism, and the possibility of a joint enquiry from very different points of departure.

Other dialogues deliberately opted for totally imaginary, indeed esoteric, situations, featuring spectres, befittingly so as these dialogues see Weber and Simmel discuss Marx and his trail of spectres and other real presences! Thus Bueno and Teixeira resolutely set their dialogue in 1923, so that Weber and Simmel can exchange their views about Lukács' History and Class Consciousness, about Lukács himself and about Marx. As they explain in their introduction (and elsewhere), they take the view that Lukács' engagement with Marxism should be read not against his previous acquaintance with Weber and Simmel, but as underpinned thereby, and, similarly, Weber is sensitive to the 'Marxian resonance' Lukács seems to have found in his writings. Here the doubled imaginary character of the dialogue serves to bring out half hidden truths, truths about their own work that were perhaps unpalatable to our thinkers. Interestingly, but perhaps unsurprisingly, Frade and Pyyhtinen also call on Lukács to cast light on some blindspots, particularly of Weber's thought, and it is Simmel's powerful invocation of an absent Lukács which forces Weber out of his reserve and leads him to make us, $21^{\text {st }}$ century readers, party to his problematic, perhaps not fully thought through conception of the people. The increasing affective tension that pervades the dialogue is underpinned by the use of their first name in their addressing each other, which is unlikely to have happened in 'real life'. That tension comes to a climax in Weber's imagined farewell letter to his deceased friend.

Finally, Theriault and Dion's dialogue both plays with utter verisimilitude, by featuring the very authors (and actors) as themselves, somewhat typified, thus (graciously!) breaking a rule of the conference; and utter distancing and artificiality, by introducing a game within the play - the 'sociologist's game', where Weber and Simmel are cards drawn, and brought in competition around a number of trials. Here too, a third, Kracauer, appears, as joker card! This is to heighten the competition and again reveal some perhaps forgotten dimensions, indeed talents (Weber as writer of a Feuilleton...)!

More dialogues were presented at the conference, but not all could be featured in the necessarily limited space of a special issue. We are thus glad to be able to refer the reader to a further published dialogue: a dialogue written by Thomas Kemple and Austin Harrington, on conflict, published in French in Sociologie et sociétés (2016).

\section{Acknowledgements}


There are a number of people we would like to thank, apart from the participants in the December 2015 conference at Edinburgh and the authors of the dialogues of this special issue, in particular, Sam Whimster, for his encouragements and discreet yet effective help since the very beginning and throughout this initiative. We would also like to acknowledge in person the reviewers of the dialogues published in this special issue. This is contrary to the convention, we know, but their contribution was also out of the ordinary, as detailed more fully above. So our most heartfelt thanks to Christopher Adair-Toteff, Anne Bowler, Cristina Delgado-García, Veronique Desnain, Jukka Gronow, Martyn Hammersley, Lucy Hinnie, Hans-Peter Mueller, Alan Scott, Igor Stiks and Michael Wood.

\section{References}

Badiou A (2013) Rhapsody for the Theatre, trans. B Bosteels. London: Verso.

Badiou A (2005) Handbook of Inaesthetics, trans. A Toscano. Stanford: Stanford University Press.

Badiou A and Kakogianni M (2015) Entretien platonicien. Lignes.

Darmon I and Frade C (2013) Introduction to the special issue: Weber, the press and sociology, then and now. Max Weber Studies 13(2): 137-150.

Dixsaut M (2016 [1985]) Le Naturel philosophe: essay sur les dialogues de Platon. Paris: Vrin.

Ghosn R and Jazairy E H (2016) Gaïa Global Circus: A Climate Tragicomedy, in Climates: Architecture and the Planetary Imaginary. New York: Lars Müller Publishers, pp. 52-61 (http://www.averyreview.com/issues/12/gaia-global-circus).

Hennis W (2000 [1987]) Max Weber's Central Question, trans. K Tribe. Newbury: Threshold Press.

Kemple T and Harrington A (2016) Dialogue fictif entre Weber et Simmel. Sociologie et sociétés 48(1): 213-219.

Latour B (2004). On using ANT for studying information systems: a (somewhat) Socratic dialogue. In Avgerou, C, Ciborra, C and Land, F (eds), The Social Study of Information and Communication Technology: Innovation, Actors, and Contexts. Oxford: Oxford University Press, pp. 62-76.

Latour B (2009) Dialogue sur deux systèmes de sociologie. In Breviglieri M, Lafaye C and Trom, D (eds), Compétences critiques et sens de la justice. Colloque de Cerisy. Paris : Economica, pp. 359-374.

Latour B (undated A) Gaia Global Circus, description. http://www.bruno-latour.fr/fr/node/359.

Labour B (undated B) A propos de Gaia Global Circus (GGC) : Réponses à quelques questions fréquentes (FAQ), http://www.brunolatour.fr/sites/default/files/downloads/FAQ\%20GAIAGLOBALCIRCUS_0.pdf 
Nanterre-Amandiers and Sciences Po (2015) MAKE IT WORK /THÉÂTRE DES NÉGOCIATIONS. http://www.cop21makeitwork.com/.

Vargas E V, Latour B, Karsenti B, Aït-Touati F, and Salmon L (2008) The Debate between Tarde and Durkheim. Environment and Planning D: Society and Space 26(5): 761-777.

Weber M (2008) Max Weber's Complete Writings on Academic and Political Vocations, ed. J Dreijmanis, trans. G C Wells. New York: Algora.

Weber M (2012) Collected Methodological Writings, ed. H H Bruun and S Whimster, trans. H H Bruun. London: Routledge.

Isabelle Darmon is a Lecturer in Sociology in the School of Social and Political Science, University of Edinburgh. Her interests are broadly in the domain of cultural sociology. Recent work in the sociology of music and food has appeared in Cultural Sociology and Food, Culture and Society. She is currently engaged in a project with Sociology and theatre colleagues and students for the writing and performance of Weber Simmel dialogues.

Carlos Frade is Senior Lecturer in Sociology at the University of Salford-Manchester. His research is concerned with the renewal of social theory along classical (Machiavellian, Marxian, Weberian) and contemporary (Badiouian) lines; it focuses on the relationship between subjectivity and power and on the possibilities for subjectivation today. He has recently published in journals such as Theory, Culture \& Society, Sociology, Situations, Cosmos and History, and Revista Española de Investigaciones Sociológicas. 